\title{
Background levels of some trace elements in weathered soils from the Brazilian Northern region
}

\author{
Francisco Souza Fadigas ${ }^{1}$; Nelson Moura Brasil do Amaral Sobrinho²; Lucia Helena Cunha \\ dos Anjos²; Nelson Mazur ${ }^{2 *}$ \\ ${ }^{1}$ UFRB/CETEC, Campus Universitário de Cruz das Almas - 4438000 - Cruz das Almas, BA - Brasil. \\ ${ }^{2}$ UFRRJ - Depto. de Solos, Br 465 - km 7 - 23890-000 - Seropédica, RJ - Brasil. \\ *Corresponding author<nelmazur@ufrrj.br>
}

\begin{abstract}
Soils formed from the Barreiras Group sediments, located mainly along the coast of Brazil Northern and Northeastern regions, generally present low concentrations of iron oxides and total organic carbon, high quantities of quartz in the sand fraction, and kaolinitic clay mineralogy. The objective of the present study was to quantify the pseudo total concentrations of $\mathrm{Cd}, \mathrm{Co}, \mathrm{Cu}, \mathrm{Cr}, \mathrm{Mn}, \mathrm{Ni}, \mathrm{Zn}$ and Fe in Xhantic Udox and Xhantic Udult soils derived from these sediments. The reference sites were covered by native vegetation and located in the States of Pará and Amapá, Brazil. Multiple linear regression analysis was applied to determine correlations between soil parameters and the levels of these metals. The best correlation was obtained between Fe, Mn, clay, and silt contents, and $\mathrm{Cd}, \mathrm{Co}, \mathrm{Cu}, \mathrm{Zn}, \mathrm{Cr}, \mathrm{Ni}$. A correlation between $\mathrm{pH}$ and these metal levels was not found. Clay and sand contents showed a negative inverse correlation with the metal levels, of same magnitude but with a different sign; this was the reason for excluding one of the parameters in the regression model. In general, the contents of the elements were lower than those found in soils formed from other parent materials. The Mn content was included in the model of multiple linear regression for $\mathrm{Cd}$ and $\mathrm{Co}$, due to its association with these last metals. Silt level showed to have a significant influence in the equations for $\mathrm{Cr}$ and $\mathrm{Co}$, which is attributed to the presence of clay minerals and $\mathrm{Fe}$ and $\mathrm{Mn}$ oxides in ferruginous and clay aggregates of silt size. The equations obtained in this paper, are useful to predict, in general terms, the amounts of those heavy metals in an unknown soil sample, if the soil material were not contaminated or affected by land usage. Thus, they may be applied to evaluate soil contamination by the studied heavy metals.
\end{abstract}

Key words: Udox, Udult, heavy metals, metal soil estimation, multiple linear regression

\section{Valores de referência de alguns elementos-traço em solos intemperizados da região Norte brasileira}

\begin{abstract}
RESUMO: Solos formados a partir de sedimentos do Grupo Barreiras apresentam, em geral, baixos teores de ferro, mineralogia caulinítica, elevadas quantidades de quartzo na fração areia e pequena quantidade de carbono orgânico. Determinaram-se os teores de Cd, Co, Cr, Ni e Zn extraídos com água régia, em bloco digestor, em Argissolos Amarelos e Latossolos Amarelos sob vegetação natural do Pará e Amapá. Regressão linear múltipla foi utilizada para correlacionar os parâmetros de solo e os teores desses metais. Melhores correlações foram obtidas entre Fe, Mn, argila, silte e Cd, Co, Cu, Zn, Cr, Ni. Não foi encontrada correlação entre o pH e os teores de metais. Argila e areia apresentaram correlação inversa com os metais, porém de mesma magnitude, sendo necessária a exclusão de uma delas no modelo de regressão. Em geral, os teores dos elementos estudados foram inferiores aos encontrados em solos formados a partir de outros materiais de origem. O Mn foi incluído no modelo de regressão linear múltipla do $\mathrm{Cd}$ e Co, em função de sua associação com esses metais. O silte foi significativo nas equações para Cr e Co, o que pode ser devido à presença de minerais de argila e óxidos de Fe e Mn em agregados ferruginosos e argilosos de tamanho silte. Estas equações podem ser úteis quando se deseja conhecer, em termos gerais, quais as quantidades que determinada amostra teria se o solo em questão não estivesse contaminado ou sujeito a uso antrópico, podendo ser utilizadas na avaliação da contaminação do solo por estes metais.

Palavras-chave: Latossolo, Argissolo, metais pesados, teor de metais no solo, regressão linear múltipla
\end{abstract}

\section{Introduction}

The total concentration of heavy metals in soils under native vegetation is primarily influenced by the type and mineralogical properties of the parent material, as well as the process by which the soil was formed, and the proportion of mineral constituents in the solid phase. Soils enriched in heavy metals mainly originate from basic igneous rocks, in which the levels of metals are higher compared with other rocks such as granites, gneisses, sandstones and siltstones (Fadigas et al., 2004; Oliveira, 1996; Tiller, 1989;). Other factors, including the proportion and composition of the clay and/or organic matter fraction, may also influence the levels of heavy metals in soils (Barona and Romero, 1996; Oliveira, 1996). For example, positive correlations were found between the amount of clay and the levels of $\mathrm{Cr}(\mathrm{r}=0.88), \mathrm{Pb}(\mathrm{r}=0.72), \mathrm{Zn}(\mathrm{r}=0.77)$ and $\mathrm{Mo}$

Sci. Agric. (Piracicaba, Braz.), v.67, n.1, p.53-59, January/February 2010 
$(r=0.80)$ (Souza et al., 1996). Similarly, positive correlations were found between the $\mathrm{Fe}_{2} \mathrm{O}_{3}$ /clay ratio and the levels of $\mathrm{Cu}$ (Santos Filho and Rocha, 1982; Valadares, 1975), $\mathrm{Fe}_{2} \mathrm{O}_{3}$ and $\mathrm{Zn}$ (Valadares and Catani, 1975), and $\mathrm{Fe}_{2} \mathrm{O}_{3}$ and $\mathrm{Co}$ (Furlani et al, 1977). Although $\mathrm{Fe}$ and $\mathrm{Mn}$ are the most abundant heavy metals in soils, their levels can be very variable. To monitor potential contamination of soil by heavy metals, it is first necessary to determine appropriate background concentrations of these elements in the soil in its natural state. The environmental impact of agriculture and/or other anthropic activities might be assessed from a comparison of the background values with those recorded in samples of soil taken from areas regarded as at risk of being contaminated.

The objective of this study was to determine equations in order to estimate the levels of $\mathrm{Cd}, \mathrm{Co}, \mathrm{Cr}, \mathrm{Ni}$ and $\mathrm{Zn}$, in soil samples from sediments of the Barreiras Group, of reference sites within Xhantic Udox and
Xhantic Udult soils under natural vegetation in the Northern States of Pará and Amapá, Brazil.

\section{Material and Methods}

\section{Soil samples}

The study was conducted using two sets of soils originated from sediments of the Barreiras Group, which date from the Tertiary period of the Cenozoic era. Set I consisted of 20 samples (Table 1) obtained from the Embrapa soil collection (Embrapa Solos, Rio de Janeiro, RJ, Brazil) and they were used to calculate multiple regression equations, from which the concentration of heavy metals in soils covered by natural vegetation could be estimated by reference to various parameters. These samples had been taken from the A and B horizons of pedons from undisturbed areas in the States of Para and Amapá, North region of Brazil. The samples were considered as representative of the most common soils

Table 1 - Municipality and State of origin, number of samples and classification of the soils.

\begin{tabular}{|c|c|c|c|c|c|}
\hline Location, Municipality (State) & $\begin{array}{l}\text { Geographical } \\
\text { Coordinates }\end{array}$ & $\begin{array}{c}\text { Number of } \\
\text { Samples }\end{array}$ & & Soil Horizon & Soil Map Unit \\
\hline \multicolumn{6}{|l|}{ Set I } \\
\hline Bujarú (PA) & $\begin{array}{c}1^{\circ} 31^{\prime 2} 1.68^{\prime \prime S} \\
48^{\circ} 02^{\prime} 35.59 " \mathrm{O} \\
\end{array}$ & 2 & & $\mathrm{~A} / \mathrm{B}$ & PAd \\
\hline \multirow{2}{*}{ Igarapé Açu (PA) } & \multirow{2}{*}{$\begin{array}{c}1^{\circ} 07^{\prime} 40.32 " \mathrm{~S} \\
47^{\circ} 36^{\prime} 56.54^{\prime \prime} \mathrm{O}\end{array}$} & 2 & & $\mathrm{~A} / \mathrm{B}$ & LAd \\
\hline & & 2 & & $\mathrm{~A} / \mathrm{B}$ & LAd \\
\hline \multirow{2}{*}{ Ipixuna (PA) } & \multirow{2}{*}{$\begin{array}{c}7^{\circ} 03^{\prime} 05.24^{\prime \prime S} \\
71^{\circ} 41^{\prime} 42.23^{\prime \prime O}\end{array}$} & 4 & & $\mathrm{~A} / \mathrm{B}$ & PAd \\
\hline & & 12 & & $\mathrm{~A} / \mathrm{B}$ & LAd \\
\hline Macapá (AP) & $\begin{array}{c}0^{\circ} 01^{\prime} 59.30 " \mathrm{~N} \\
51^{\circ} 04^{\prime} 11.49 " \mathrm{O}\end{array}$ & 6 & & $\mathrm{~A} / \mathrm{B}$ & LAd \\
\hline Maracanã (PA) & $\begin{array}{c}0^{\circ} 47^{\prime} 15.94 " \mathrm{~S} \\
47^{\circ} 27^{\prime} 16.13 \text { "O }\end{array}$ & 2 & & $\mathrm{~A} / \mathrm{B}$ & PAd \\
\hline Paragominas (PA) & $\begin{array}{c}2^{\circ} 59^{\prime} 50.59 " \mathrm{~S} \\
47^{\circ} 22^{\prime} 18.65^{\prime \prime} \mathrm{O}\end{array}$ & 4 & & $\mathrm{~A} / \mathrm{B}$ & LAd \\
\hline \multirow{2}{*}{$\begin{array}{l}\text { São Domingos do Capim } \\
\text { (PA) }\end{array}$} & \multirow{2}{*}{$\begin{array}{c}1^{\circ} 40^{\prime} 28.67 " \mathrm{~S} \\
47^{\circ} 46^{\prime} 04.12^{\prime \prime O}\end{array}$} & 2 & & $\mathrm{~A} / \mathrm{B}$ & PAd \\
\hline & & 2 & & $\mathrm{~A} / \mathrm{B}$ & PAe \\
\hline São Franciso do Pará (PA) & $\begin{array}{c}1^{\circ} 10^{\prime} 15.13 " \mathrm{~S} \\
47^{\circ} 47^{\prime} 36.14 \text { "O }\end{array}$ & 2 & & $\mathrm{~A} / \mathrm{B}$ & PAd \\
\hline Set II & & Sample number & Soil Coverage & & \\
\hline \multirow{2}{*}{ Uruará (PA) } & \multirow{2}{*}{$\begin{array}{c}3^{\circ} 43^{\prime} 45.49^{\prime \prime S} \\
53^{\circ} 44^{\prime} 36.18^{\prime \prime O}\end{array}$} & I & forest & A & PAd \\
\hline & & II & forest & B & PAd \\
\hline \multirow{6}{*}{ Campos dos Goytacazes (RJ) } & \multirow{6}{*}{$\begin{array}{l}21^{\circ} 45^{\prime} 20.46 " \mathrm{~S} \\
41^{\circ} 19^{\prime} 25.80^{\prime \prime O}\end{array}$} & III & secondary forest & A & LAc \\
\hline & & IV & secondary forest & B & LAc \\
\hline & & $\mathrm{V}$ & secondary forest & A & LAd \\
\hline & & VI & secondary forest & B & LAd \\
\hline & & VII & pasture & A & LAd \\
\hline & & VIII & pasture & $\mathrm{B}$ & LAd \\
\hline
\end{tabular}

${ }^{\text {aPAd }}=$ Argissolo Amarelo Distrófico (Xhantic Udult); LAc = Latossolo Amarelo Coeso (Xhantic Udox); LAd = Latossolo Amarelo Distrófico (Xhantic Udox). Brazilian Soil Classification System (Soil Taxonomy). 
present at those States and originated from the Barreiras Group sediments. Sampling was performed between 1992 and 1997, and the pedons were reclassified according to Brazilian System of Soil Classification (SiBCS) (EMBRAPA, 2006) as "Latossolo Amarelo" and "Argissolo Amarelo", being equivalent to the subgroups Xhantic Udox and Xhantic Udult, of the Soil Taxonomy, respectively (USDA, 1999). Set II consisted of eight samples (Table 1) taken from sites under three types of vegetation (forest, secondary forest and pasture) located in the States of Pará and Rio de Janeiro, North and Southeast regions of Brazil, respectively. These samples were used to validate the developed equations.

\section{Soil analysis}

The amount of organic carbon was determined by moist oxidation, the soil mineral elements expressed in the oxide form $\left(\mathrm{Fe}_{2} \mathrm{O}_{3}, \mathrm{Al}_{2} \mathrm{O}_{3}, \mathrm{SiO}_{2}\right.$ and $\mathrm{TiO}_{2}$, as determined by sulphuric acid extraction method in the less than $2 \mathrm{~mm}$ fraction. Cation exchange capability (CEC), $\mathrm{pH}$ in water (potentiometry), and particle size (clay, silt and sand by the pipette method), were determined for each sample according to EMBRAPA (1997) methods. Heavy metals (Cd, Co, Cu, Cr, Mn, Ni, Zn, and $\mathrm{Fe}$ ) were extracted using a modified version of the McGrath and Cunliffe (1985). A $250 \mathrm{mg}$ sample was ground to a fine powder, using a mortar and pestle, sieved through a 100 mesh sieve $(145 \mu \mathrm{m})$ and digested with of aqua regia $\left(\mathrm{HCl} / \mathrm{HNO}_{3} 3: 1 \mathrm{v} / \mathrm{v}\right.$ solution). The pseudototal concentration of metals, which included metal ions that are readily exchangeable between the solid and solution phases together with those that are more strongly bound within the soil solid phases, was determined by inductively coupled plasma atomic emission spectroscopy (ICP - OES) under following condition: Power:1500 W; Flow of Argon: $\mathrm{L} \mathrm{min}^{-1}$; Plasma:15; Auxiliar:0.8; Nebulizer:0.7; Flow sample: $2 \mathrm{~L} \mathrm{~min}^{-1}$; Type of nebulizer: Cross flow; Number of replicates:3. Reading wavelength (nm): Cd 214.43; Cr 205.56; Mn 257.61; Ni 232.00; Co 228.61; Fe 238.20; Pb 220.53; Zn 213.85.

\section{Statistical analysis}

Pearson correlation coefficients were calculated in order to study correlations between the physical and chemical characteristics of the soil samples, and between such characteristics and the heavy metal content. Multiple linear regression analyses was used to construct equations applied in the estimation of metal concentrations in natural soil samples. Statistical analyses were performed with the aid of Statistica version 5.0 (StatSoft, 1995) software. Analytical data obtained for the A and B horizons were considered jointly in the statistical analyses. Results of metals below the levels of detection of the analytical method were eliminated from the analyses.

\section{Results and Discussion}

Based in SiBCS criteria (EMBRAPA, 2006), Brazilian soils may be classified according to their $\mathrm{Fe}$ content as follows: soils low in $\mathrm{Fe}\left(\mathrm{Fe}_{2} \mathrm{O}_{3}<80 \mathrm{~g} \mathrm{~kg}^{-1}\right)$, soils contain intermediate levels of $\mathrm{Fe}\left(\mathrm{Fe}_{2} \mathrm{O}_{3}\right.$ between 80 and $\left.180 \mathrm{~g} \mathrm{~kg}^{-1}\right)$ and soils rich in $\mathrm{Fe}\left(\mathrm{Fe}_{2} \mathrm{O}_{3}\right.$ between 18 and $\left.<36 \mathrm{~g} \mathrm{~kg}^{-1}\right)$. Soils formed from sediments of the Barreiras Group have low levels of nutrients, the iron oxide (predominantly goethite) content is very low, the clay mineralogy is kaolinitic, and most of the sand fraction consists of quartz grains with some ferruginous concretions (Jacomine, 1996; Ribeiro, 1996).

\section{Characteristics of the soils included in the Sets I}

The pseudototal concentrations of $\mathrm{Cd}, \mathrm{Co}, \mathrm{Cu}, \mathrm{Cr}, \mathrm{Mn}$, $\mathrm{Ni}, \mathrm{Zn}$ and $\mathrm{Fe}$ in the Xhantic Udox and Xhantic Udult from set $I$ are shown in Table 2 . In general, the mean concentration values were lower than those reported in Ross (1994) and CETESB (2005)). This finding probably reflects the different chemical and physical characteristics of the studied soils, rather than implying a low efficiency of the aqua regia method of extraction of metals when compared with other methods (Diaz Barrientos et al., 1991).

The pseudototal concentration of $\mathrm{Fe}$ in the soils studied varied between 1.84 and $21.87 \mathrm{~g} \mathrm{~kg}^{-1}$, confirming that the samples from set were relatively poor in $\mathrm{Fe}$, while the concentration of $\mathrm{Mn}$ varied between 13.8 and $182 \mathrm{mg} \mathrm{kg}^{-1}$. The mean values of these elements were similar to those reported by Saldanha et al. (1997) in studies with Brazilian soils (A and $\mathrm{B}$ horizons), in which the extraction of metals was performed using aqua regia in a microwave assisted procedure. According to Saldanha et al. (1997), Fe concentration in soils varied from 2 to $132 \mathrm{~g} \mathrm{~kg}^{-1}$ (A horizon) and 5.9 to $138.5 \mathrm{~g} \mathrm{~kg}^{-1}$ (B horizon), while Mn varied from 21 to $1216 \mathrm{mg} \mathrm{kg}^{-1}$ (A horizon) and from 11 to $482 \mathrm{mg} \mathrm{kg}^{-1}$ (B horizon). However, in the present study the highest concentrations of Fe found were circa 6 fold lower than the values reported by Saldanha et al. (1997). Such differences may be explained by the fact that those authors analyzed soils derived from different parent materials including iron rich igneous rocks such as basalts.

Levels of $\mathrm{Cu}, \mathrm{Zn}$ and $\mathrm{Co}$ found in the soil samples studied were very low compared with those reported for soils derived from basic rocks and alluvial sediments, but were similar to values obtained with the perchloric-fluoride extraction method for soils derived from sandstone and sandy sediments (Furlani et al., 1977; Valadares, 1975; Valadares and Catani, 1975). The average concentration of $\mathrm{Zn}$ was $7.70 \mathrm{mg} \mathrm{kg}^{-1}$, which was lower than the smallest value found in other soils. The element $\mathrm{Cu}$ was not detected in many soils samples. Probably, the low organic carbon content and the fact that the aqua regia method does not dissolve the residual fraction contributed to this result, since most of the $\mathrm{Cu}$ in soil is associated with these two fractions (McLaren and Crawford, 1973).

Levels of Ni detected in the samples under study were similar to those found by Rovers et al. (1983) in soils derived from sandy sediments and other materials in São Paulo State, such as Entisols (R), Rhodic Oxisols (LEa) and Distrudox (LVa) and with a perchloric-fluoride extraction method. Conversely, the concentrations of $\mathrm{Ni}$ in the studied samples were inferior to those found in soils derived from basic igneous rocks, such as Lithic Entisols (Li b), clayey Rhodic Udults (TE), clayey Rhodic Dystrudox (LRd) and clayey Rhodic Eutrudox (LRe). 
Table 2 - Pseudototal concentrations of metals, physical and chemical characteristics, and content of minerals expressed in oxide form in Set I groups soils originated from the Barreiras Group sediments ${ }^{a}$.

\begin{tabular}{|c|c|c|c|c|c|c|}
\hline & Determination $(n)$ & Mean & Confidence interval ${ }^{\mathrm{b}}$ & Minimum value & Maximum value & Standard deviation \\
\hline \multicolumn{7}{|c|}{ Metal concentration ${ }^{\mathrm{c}}\left(\mathrm{mg} \mathrm{kg}^{-1}\right)$, unless $\mathrm{Fe}\left(\mathrm{g} \mathrm{kg}^{-1}\right)$} \\
\hline $\mathrm{Cd}$ & 37 & 0.3 & 0.1 & 0.1 & 0.9 & 0.2 \\
\hline Co & 40 & 1.7 & 0.3 & 0.2 & 3.4 & 0.9 \\
\hline $\mathrm{Cr}$ & 40 & 26.8 & 5.1 & 3.0 & 55.3 & 16.4 \\
\hline $\mathrm{Cu}$ & 29 & 1.1 & 0.2 & 0.3 & 2.2 & 0.6 \\
\hline $\mathrm{Mn}$ & 40 & 49.0 & 11.6 & 13.8 & 182.8 & 37.5 \\
\hline $\mathrm{Ni}$ & 39 & 6.6 & 1.4 & 0.7 & 15.7 & 4.4 \\
\hline $\mathrm{Zn}_{\mathrm{n}}$ & 40 & 7.7 & 1.3 & 1.5 & 17.8 & 4.1 \\
\hline $\mathrm{Fe}$ & 40 & 10.1 & 1.9 & 1.8 & 21.87 & 6.2 \\
\hline \multicolumn{7}{|c|}{ Physical and chemical soil characteristics } \\
\hline Silt $\left(\mathrm{g} \mathrm{kg}^{-1}\right)$ & 40 & 74 & 13 & 10 & 190 & 41 \\
\hline Clay $\left(\mathrm{g} \mathrm{kg}^{-1}\right)$ & 40 & 280 & 61 & 40 & 840 & 196 \\
\hline Sand $\left(\mathrm{g} \mathrm{kg}^{-1}\right)$ & 40 & 645 & 70 & 70 & 940 & 226 \\
\hline $\mathrm{pH}$ in water & 40 & 4.6 & 0.1 & 3.6 & 5.5 & 0.5 \\
\hline CEC $\left(\mathrm{mmol} \mathrm{dm}{ }^{-3}\right)^{\mathrm{d}}$ & 40 & 49 & 117 & 160 & 195 & 37.8 \\
\hline $\mathrm{C}\left(\mathrm{g} \mathrm{dm} \mathrm{dm}^{-3}\right)$ & 40 & 8.9 & 2.7 & 1.7 & 38.3 & 8.7 \\
\hline \multicolumn{7}{|c|}{ Mineral elements expressed in the oxide form } \\
\hline $\mathrm{SiO}_{2}\left(\mathrm{~g} \mathrm{~kg}^{-1}\right)^{\mathrm{e}}$ & 40 & 109.4 & 21.4 & 23.0 & 276.0 & 68.9 \\
\hline $\mathrm{Al}_{2} \mathrm{O}_{3}$ & 40 & 100.3 & 24.5 & 7.0 & 329.0 & 78.9 \\
\hline $\mathrm{Fe}_{2} \mathrm{O}_{3}$ & 40 & 19.2 & 4.3 & 2.0 & 59.0 & 14.0 \\
\hline $\mathrm{TiO}_{2}$ & 40 & 8.5 & 1.8 & 1.4 & 27.6 & 5.8 \\
\hline
\end{tabular}

${ }^{a}$ Samples were taken from horizons $\mathrm{A}$ and $\mathrm{B}$; ${ }^{\mathrm{b}}$ Probability defined at $p \leq 0.05$. ${ }^{\mathrm{c} E x t r a c t i o n}$ carried out with aqua regia $(\mathrm{HCl} / \mathrm{HNO} 3$ $3: 1 \mathrm{v} / \mathrm{v}$ solution). ${ }^{\mathrm{d}} \mathrm{CEC}=$ cation exchange capability; ${ }^{\mathrm{e}}$ Extracted by sulphuric acid attack in the fraction less than $2 \mathrm{~mm}$.

The content of Cd varied between 0.06 and $0.86 \mathrm{mg} \mathrm{kg}^{-1}$, which was within the range previously published (0.005 to $2.4 \mathrm{mg} \mathrm{kg}^{-1}$; Souza et al., 1996), and the mean concentration $\left(0.30 \mathrm{mg} \mathrm{kg}^{-1}\right)$ was similar to the value reported for soils under secondary forest vegetation in which the extraction of metals was performed using aqua regia (Ramalho et al., 2000). The concentration of $\mathrm{Cr}$ was similar to that reported by Souza et al. (1996), i.e., between 18.7 and $285 \mathrm{mg} \mathrm{kg}^{-1}$.

The amounts of clay and sand fractions in the soil samples varied considerably, from 40 to $840 \mathrm{~g} \mathrm{~kg}^{-1}$ and 70 to $940 \mathrm{~g} \mathrm{~kg}^{-1}$, respectively (Table 2). The reason for such large variability is that the samples were collected in both $\mathrm{A}$ and $\mathrm{B}$ horizons, and those from horizon A contained more sand while the ones from B horizon had more clay. Considering only the mean values, regardless of the horizons, there was a predominance of medium textured (sandy clayey loam) soils and this accounted for the low levels of metals present. It is noted that the content of silt in soils formed from Barreiras Group sediments is low (Table 2), which also contributes for the low levels of metals.

\section{Correlation studies}

The correlation's coefficients values for Set I samples (Table 3$)$ indicated strong positive $(p<0.05)$ correla- tions between the level of $\mathrm{Fe}$ and the contents of all other metals, except for $\mathrm{Cu}$; thus, $\mathrm{Fe}$ was included as a variable in the linear regression equations. Significant correlations were also found between the levels of both $\mathrm{Cr}$ and $\mathrm{Ni}$ and those of the other metals studied (except $\mathrm{Cu}$ ). The weakest correlation was between $\mathrm{Cd}$ and the other metals. Mn was included as a variable in the construction of the linear regression equations because of its strong significant correlation with $\mathrm{Cd}$ and $\mathrm{Co}$.

The contents of both clay and sand were significantly correlated with the concentration of all metals, except for $\mathrm{Cu}$, and the strengths of such associations were of similar magnitudes but of opposing signs. Considering the redundancy of information in the two variables, it was necessary to exclude one of these variables (sand) from the linear regression model. The content of silt exhibited significant positive correlations with the concentration of all metals (except $\mathrm{Cu}$ ), and this may be explained by the presence of clay minerals and $\mathrm{Fe}$ and $\mathrm{Mn}$ oxides associated forming silt sized aggregates (Klamt and Van Reeuwijk, 2000; Melo et al., 2000). No significant correlations were detected between the concentrations of heavy metals and the CEC or carbon content of the soil samples (Table 4). Similarly, $\mathrm{pH}$ was not correlated with the amounts of heavy met- 
Table 3 - Pearson's correlation coefficients for associations between metal concentrations in Set I group of soils originated from the Barreiras Group sediments.

\begin{tabular}{lllllllll}
\hline Metal & $\mathrm{Cr}$ & $\mathrm{Co}$ & $\mathrm{Ni}$ & $\mathrm{Cu}$ & $\mathrm{Zn}$ & $\mathrm{Cd}$ & $\mathrm{Mn}$ & $\mathrm{Fe}$ \\
\hline $\mathrm{Cr}$ & 1.00 & & & & & & & \\
$\mathrm{Co}$ & $0.82 *$ & 1.00 & & & & & & \\
$\mathrm{Ni}$ & $0.84 *$ & $0.79 *$ & 1.00 & & & & & \\
$\mathrm{Cu}$ & $0.38^{*}$ & 0.35 & 0.32 & 1.00 & & & & \\
$\mathrm{Zn}$ & $0.93 *$ & $0.85 *$ & $0.87 *$ & $0.42 *$ & 1.00 & & & \\
$\mathrm{Cd}$ & $0.58 *$ & $0.64 *$ & $0.73 *$ & 0.05 & $0.59 *$ & 1.00 & & \\
$\mathrm{Mn}$ & $0.51 *$ & $0.60 *$ & $0.59 *$ & 0.23 & $0.51 *$ & $0.72 *$ & 1.00 & \\
$\mathrm{Fe}$ & $0.90 *$ & $0.82 *$ & $0.95^{*}$ & $0.38^{*}$ & $0.93 *$ & $0.71 *$ & $0.61 *$ & 1.00 \\
\hline
\end{tabular}

${ }^{2}$ Correlations marked with *are significant $(p<0.05)$.

Table 4-Pearson's correlation coefficients ${ }^{\mathrm{a}}$ for associations between physical and chemical characteristics and metal concentrations in Set I groups soils originated from the Barreiras Group sediments.

\begin{tabular}{|c|c|c|c|c|c|c|c|c|}
\hline \multirow{2}{*}{$\begin{array}{l}\text { Physical and chemical } \\
\text { characteristics }\end{array}$} & \multicolumn{8}{|c|}{ Metal concentration } \\
\hline & $\mathrm{Cr}$ & Co & $\mathrm{Ni}$ & $\mathrm{Cu}$ & $\mathrm{Zn}$ & $\mathrm{Cd}$ & $\mathrm{Mn}$ & $\mathrm{Fe}$ \\
\hline Silt & $0.46 *$ & $0.43 *$ & $0.47 *$ & 0.14 & $0.57 \%$ & $0.46 *$ & $0.67 *$ & 0.56 \\
\hline Clay & $0.75 *$ & $0.60 *$ & $0.74 *$ & 0.17 & $0.69 *$ & $0.65 *$ & $0.68 *$ & $0.76 \%$ \\
\hline Sand & $0.74 *$ & $0.60 *$ & $0.73^{*}$ & 0.17 & $0.70 \%$ & $0.64 *$ & $0.71 *$ & $0.76 *$ \\
\hline $\mathrm{pH}$ in water & 0.03 & 0.24 & 0.14 & 0.27 & 0.01 & 0.24 & $0.32 *$ & 0.08 \\
\hline $\mathrm{CEC}^{\mathrm{b}}$ & 0.18 & 0.25 & 0.16 & 0.23 & 0.15 & 0.02 & 0.27 & 0.12 \\
\hline Carbon & 0.15 & 0.21 & 0.13 & 0.17 & 0.10 & 0.00 & 0.29 & 0.08 \\
\hline
\end{tabular}

${ }^{a}$ Correlations marked with *are significant $(p<0.05) ;{ }^{\mathrm{b}} \mathrm{CEC}=$ cation exchange capability.

als present in the soil (with the possible exception of $\mathrm{Mn}$ ), a finding in agreement with that reported by Qian et al. (1996) following studies involving acid extraction of metals from different soil fractions. Since the contributions of $\mathrm{pH}, \mathrm{CEC}$ and carbon content in the evaluation of metal concentration in the soils studied were negligible, they were excluded from the linear regression model.

The Pearson correlation coefficients relating to associations between the physical and chemical characteristics and the content of minerals expressed in oxide form (Table 5) revealed a strong inverse $(p<0.05)$ correlation $(r=0.99)$ between the clay and sand content of in these soils. While the correlations between carbon content, CEC and $\mathrm{pH}$ and the other physical and chemical characteristics (i.e., silt, clay and sand) were not significant at $p \leq 0.05$, there was a strong positive correlation $(\mathrm{r}=0.96)$ between carbon content and CEC. There were also strong positive correlations between the minerals expressed in oxide form $\left(\mathrm{Fe}_{2} \mathrm{O}_{3}, \mathrm{Al}_{2} \mathrm{O}_{3}, \mathrm{SiO}_{2}\right.$ and $\left.\mathrm{TiO}_{2}\right)$ present in the samples and the silt and clay fractions (Table 5). However, these associations arose from the fact that the elements Si, Al, Fe and Ti were determined using the sulphuric acid extraction method and derived predominantly from the silt and clay fractions (EMBRAPA, 1997). For this reason variables relating to mineral content were not included in the linear regression model.

\section{Multiple linear regression equations}

The software Statistica version 5.0 (StatSoft, 1995) was used in order to select the variables that should remain in the regression model, and to test the significance of the adjustment $\left(R^{2}\right)$ and intercept. Outliers were also detected using the methodology proposed by the statistical software employed: in some cases, these values were excluded, although in a minimum number of cases (35) they were preserved in the definition of each regression equation.

The variables clay, silt, $\mathrm{Fe}$ and $\mathrm{Mn}$ were finally selected in the development of equations representing the concentrations of $\mathrm{Cd}, \mathrm{Co}, \mathrm{Cr}, \mathrm{Ni}$ and $\mathrm{Zn}$ in the Xhantic Udox and Xhantic Udult under native vegetation coverage in the Set I samples (Table 6). It was impossible to obtain a satisfactory equation for $\mathrm{Cu}$ since the correlations between this element and other variables were low. The inclusion of silt in the equations built for $\mathrm{Cr}$ and $\mathrm{Co}$ was significant owing to the presence of strong silt sized aggregates formed clay minerals and oxides, and the lack of efficiency of the dispersion process during the particle size analysis to separate the aggregates (Klamt and Reeuwijk, 2000; Melo et al., 2000). The total concentrations of $\mathrm{Si}, \mathrm{Al}, \mathrm{Fe}$ and $\mathrm{Ti}$ were not considered in the equations, although there was some correlation with the pseudo total concentration of other metals. The inclusion of these elements as variables would demand further analysis and, consequently, would imply in more time and costs. Be- 
Table 5 - Pearson's correlation coefficients ${ }^{a}$ for associations between physical and chemical characteristics and content of minerals expressed in oxide form in Set I groups of soils originated from the Barreiras Group sediments.

\begin{tabular}{|c|c|c|c|c|c|c|c|c|c|c|}
\hline Variable & Silt & Clay & Sand & $\mathrm{pH}$ & $\mathrm{CEC}^{\mathrm{b}}$ & $C$ & $\mathrm{SiO}_{2}$ & $\mathrm{Al}_{2} \mathrm{O}_{3}$ & $\mathrm{Fe}_{2} \mathrm{O}_{3}$ & $\mathrm{TiO}_{2}$ \\
\hline Silt & 1.00 & & & & & & & & & \\
\hline Clay & $0.69 *$ & 1.00 & & & & & & & & \\
\hline Sand & $0.78^{*}$ & $0.99 *$ & 1.00 & & & & & & & \\
\hline $\mathrm{pH}$ & 0.24 & 0.05 & 0.08 & 1.00 & & & & & & \\
\hline CEC & $0.52^{*}$ & 0.17 & 0.24 & 0.27 & 1.00 & & & & & \\
\hline C & $0.53^{*}$ & 0.15 & 0.22 & 0.26 & $0.96^{*}$ & 1.00 & & & & \\
\hline $\mathrm{SiO}_{2}$ & $0.71 *$ & $0.95^{*}$ & $0.96 *$ & 0.01 & 0.21 & 0.16 & 1.00 & & & \\
\hline $\mathrm{Al}_{2} \mathrm{O}_{3}$ & $0.74^{*}$ & $0.97 *$ & $0.97^{*}$ & 0.02 & 0.25 & 0.21 & $0.97 *$ & 1.00 & & \\
\hline $\mathrm{Fe}_{2} \mathrm{O}_{3}$ & $0.66^{*}$ & $0.82 *$ & $0.83^{*}$ & 0.13 & 0.06 & 0.06 & $0.80^{*}$ & $0.87 *$ & 1.00 & \\
\hline $\mathrm{TiO}_{2}$ & $0.69 *$ & $0.88^{*}$ & $0.89 *$ & 0.23 & 0.23 & 0.21 & $0.81 *$ & $0.89 *$ & $0.79 *$ & 1.00 \\
\hline
\end{tabular}

${ }^{\mathrm{a}}$ Correlations marked with *are significant $(p<0.05) ;{ }^{\mathrm{b}} \mathrm{CEC}=$ cation exchange capability.

Table 6 - Equations developed in order to estimate the concentrations of Cd, Co, Cr, Zn, Ni in Sets I groups soils originated from the Barreiras Group sediments.

\begin{tabular}{|c|c|c|}
\hline Metal & Multiple linear regression equation ${ }^{a}$ & Determination coefficient $\left(\mathrm{R}^{2}\right)^{\mathrm{b}}$ \\
\hline $\mathrm{Cd}$ & $\left.\hat{\mathrm{Y}} \mathrm{Cd}=10^{(0.107 \log \mathrm{Fe}}+0.62 \log \mathrm{Mn}-1.067\right) / 100$ & $0.78^{* * 1}$ \\
\hline Co & $\hat{\mathrm{Y}} \mathrm{Co}=1.836 \log \mathrm{Fe}+2.159 \log \mathrm{Mn}-0.834 \log \mathrm{Silt}-7.37$ & $0.92 * *$ \\
\hline $\mathrm{Cr}$ & $\hat{\mathrm{Y}} \mathrm{Cr}=46.148 \log \mathrm{Fe}-14.8 \log \mathrm{Silt}+14.612 \log C l a y-164.207$ & $0.90 * *$ \\
\hline $\mathrm{Ni}$ & $\left.\hat{\mathrm{Y}} \mathrm{Ni}=10^{(0.87 \log F e}+0.202 \log \mathrm{Clay}-3.183\right)$ & $0.95^{* *}$ \\
\hline $\mathrm{Zn}_{\mathrm{n}}$ & $\hat{\mathrm{Y}} \mathrm{Z}_{\mathbf{n}}=10^{(0.878 \log \mathrm{Fe}-0.044 \log \mathrm{Clay}-2.537)}$ & $0.94^{* *}$ \\
\hline
\end{tabular}

${ }^{a}$ Use $\mathrm{Fe}$ and $\mathrm{Mn}$ concentrations in $\mathrm{mg} \mathrm{kg}^{-1}$; Silt and clay in $\mathrm{g} \mathrm{kg}^{-1}$. ${ }^{\mathrm{b}}$ Correlations marked with * or **are significant at $p<0.05$ and 0.01 , respectively, according to the $\mathrm{F}$ test.

Table 7 - Comparison between the values estimated for metal concentrations through the linear regression equations and the values found in Set II groups soils originated from the Barreiras Group sediments.

\begin{tabular}{|c|c|c|c|c|c|c|c|c|c|c|c|c|c|c|}
\hline \multirow{2}{*}{$\begin{array}{l}\text { Soil } \\
\text { samples }\end{array}$} & \multirow{2}{*}{$\begin{array}{l}\text { Silt } \\
\mathrm{DV}^{\mathrm{a}}\end{array}$} & \multirow{2}{*}{$\begin{array}{l}\text { Clay } \\
\text { DV }\end{array}$} & \multirow{2}{*}{$\begin{array}{l}\mathrm{Fe} \\
\mathrm{DV}\end{array}$} & \multirow{2}{*}{$\begin{array}{l}\mathrm{Mn} \\
\mathrm{DV}\end{array}$} & \multicolumn{2}{|r|}{$\mathrm{Cd}$} & \multicolumn{2}{|r|}{ Co } & \multicolumn{2}{|r|}{$\mathrm{Cr}$} & \multicolumn{2}{|r|}{$\mathrm{Ni}$} & \multicolumn{2}{|r|}{$\mathrm{Zn}_{\mathrm{n}}$} \\
\hline & & & & & DV & $\mathrm{EV}^{\mathrm{b}}$ & DV & $\mathrm{EV}$ & DV & $\mathrm{EV}$ & DV & $\mathrm{EV}$ & DV & $\mathrm{EV}$ \\
\hline & ----- & $\mathrm{g} \mathrm{kg}^{-1}$ & - & ---- & . & - & $\cdots$ & - & - n & $\mathrm{g} \mathrm{kg}$ & & - & . & - \\
\hline I & 110 & 310 & 12.1 & 103.9 & 0.5 & $0.4-0.6$ & 1.7 & $2.5-2.9$ & 14.1 & $27.8-33.0$ & 6.35 & $7.4-8.3$ & 5.1 & $7.9-8.9$ \\
\hline II & 70 & 570 & 23.9 & 125.5 & 1.0 & $0.6 \quad 0.9$ & 2.6 & $3.4-3.8$ & 29.4 & $48.8-53.7$ & 12.65 & $14.8-17.8$ & 8.8 & $13.5-16.2$ \\
\hline III & 80 & 290 & 10.1 & 26.5 & 0.4 & $0.2 \quad 0.3$ & 2.0 & $1.3-1.5$ & 20.9 & $26.5-30.3$ & 6.67 & $6.3 \quad 6.9$ & 8.0 & $6.8-7.6$ \\
\hline IV & 60 & 430 & 15.6 & 30.3 & 0.6 & $0.2-0.3$ & 2.8 & $1.8-2.1$ & 34.5 & $39.2-43.5$ & 10.45 & $9.8-11.2$ & 11.2 & $9.5-11.0$ \\
\hline $\mathrm{V}$ & 60 & 150 & 5.1 & 66.5 & 0.2 & $0.2-0.3$ & 2.3 & $1.7-2.0$ & 11.9 & $9.7-14.7$ & 3.39 & $3.0-3.4$ & 3.7 & $3.8-4.4$ \\
\hline VI & 70 & 310 & 10.0 & 33.9 & 0.3 & $0.2-0.3$ & 2.7 & $1.6-1.8$ & 23.6 & $28.0-31.2$ & 6.48 & $6.5-7.1$ & 6.0 & $6.6-7.6$ \\
\hline VII & 90 & 90 & 6.2 & 90.1 & 0.3 & $0.3-0.4$ & 3.1 & $1.9-2.3$ & 14.8 & $5.4-15.4$ & 3.47 & $3.1-3.8$ & 3.6 & $4.8-5.9$ \\
\hline VIII & 80 & 190 & 9.2 & 46.9 & 0.4 & $0.2-0.3$ & 3.5 & $1.8-2.0$ & 21.9 & $21.3-26.6$ & 5.2 & $5.4-6.0$ & 4.4 & $6.6-7.4$ \\
\hline
\end{tabular}

${ }^{\mathrm{a}} \mathrm{DV}=$ determined values (coupled plasma atomic emission spectroscopy); ${ }^{\mathrm{E}} \mathrm{EV}=$ Confidence interval estimated to multiple linear regression equation $(p=0.05)$.

sides, when such variables were tested, they did not contribute to a better adjustment of the equations (Table 6).

Set II samples (collected from areas of forest, secondary forest and pasture) were analyzed to compare the concentration of metals present in the soils as estimated by the equations above and the amounts of metals in an unknown soil. The Table 7 shows a comparison of the concentrations of $\mathrm{Cd}, \mathrm{Co}, \mathrm{Cr}, \mathrm{Ni}$ and $\mathrm{Zn}$ determined in this set and those predicted from the measured values of silt, clay, $\mathrm{Mn}$ and $\mathrm{Fe}$ as represented by the equations shown in Table 7. In general, the equations for $\mathrm{Cr}$ and $\mathrm{Zn}$ tend to overestimate the levels of these elements, especially in horizons rich in clay and Fe. This is a consequence of low concentrations of $\mathrm{Fe}$ in the samples used to obtain the equations. Thus, for soils with Fe contents greater than $10 \mathrm{~g} \mathrm{~kg}^{-1}$ (extracted with aqua regia), it is ex- 
pected to occur more deviation in the values of concentrations calculated. For $\mathrm{Cd}$, the estimated values were generally lower than those determined. However, this difference becomes less important when we consider values less than $1 \mathrm{mg} \mathrm{kg}^{-1}$ soil. These equations can be used to obtain approximate values of the concentrations of these metals in soils similar to the ones of this study.

\section{Conclusions}

The levels of heavy metals in Xhantic Udox and Xhantic Udult soil samples originated from the Barreiras Group sediments were lower than those found in soils cited by different authors, especially when in comparison to soils formed from basalt igneous rocks. The obtained equations can be used to obtain approximated concentrations of $\mathrm{Cd}, \mathrm{Co}, \mathrm{Cr}, \mathrm{Zn}$ and $\mathrm{Ni}$ in Xhantic Udox and Xhantic Udult soil samples based on the contents of clay, silt, $\mathrm{Fe}$ and $\mathrm{Mn}$.

\section{Acknowledgements}

To thank CAPES and CPGA CS for financial support and Embrapa Solos for technical assistance.

\section{References}

Barona, A.; Romero, F. 1996. Distribuition of metals in soils relationships among fractions by principal component analysis. Soil Technology 8: 303-319.

Companhia de Tecnologia de Saneamento [CETESB]. Ambiental: Guiding values for soils and groundwater in the State of Sao Paulo. 2005. Available at: www.cetesb.sp.gov.br/Solo/relatorios/ tabela_valores_2005.pdf. [Accessed Oct. 28, 2008].

Diaz Barrientos, E.; Madrid, L.; Cabrera, F.; Contreras, M.C. 1991. Comparison of two methods of sample preparation for determination by atomic absorption spectrophotometry of heavy metals in soils and sediments. Communications in Soil Science and Plant Analysis 22: 1559-1568.

Empresa Brasileira de Pesquisa Agropecuária [EMBRAPA]. 1997. Manual of Methods for Soil Analysis. 2ed. Embrapa-Serviço Nacional de Levantamento e Conservação de Solos, Rio de Janeiro, RJ. Brazil.

Empresa Brasileira de Pesquisa Agropecuária [EMBRAPA]. 2006. Brazilian System of Soil Classification. 2ed. Embrapa-Centro Nacional de Pesquisa de Solos, Rio de Janeiro, RJ. Brazil. 306p (in Portuguese, with abstract in English).

Fadigas, F.S.; Moura, Amaral Sobrinho, N.M.B. do, Mazur, N.; Anjos, L.H.C. 2006. Estimation of Reference Values for Cadmium, Cobalt, Chromium, Copper, Nickel, Lead, and Zinc in Brazilian Soils. Communications in Soil Science and Plant Analysis 37: 945-959.

Furlani, P.R.; Bataglia, O.A.; Valadares, J.M.A. 1977. Cobalt in soils of the State of São Paulo. Revista Brasileira de Ciência do Solo 1: 65-67.

Jacomine, P.K.T. 1996. Geographical distribution, characteristics and classification of cohesive soils of the coastal tableland. p.13-26. In: Nogueira, L.R.Q.; Nogueira, L.C., eds. Pesquisa e desenvolvimento para os tabuleiros costeiros. Embrapa Tabuleiros Costeiros, Aracajú, SE. Brazil.
Klamt, E.; Van Reeuwijk, L.P. 2000. Evaluation of morphological, physical and chemical characteristics of ferralsols and related soils. Revista Brasileira de Ciência do Solo 24: 573-587. (in Portuguese, with abstract in English)

Mcgrath, S.P.; Cunliffe, C.H. 1985. A simplified method for the extraction of metals $\mathrm{Fe}, \mathrm{Zn}, \mathrm{Cu}, \mathrm{Ni}, \mathrm{Cd}, \mathrm{Pb}, \mathrm{Cr}$, Co and $\mathrm{Mn}$ from soils and sewage sludges. Journal of the Science of Food and Agriculture 36: 794-798.

Mclaren, R.G.; Crawford, D.V. 1973. Studies on soils: copper. I. The fractionation of copper in soils. Journal of Soil Science 24: 172-181.

Melo, V.F.; Novais, R.F.; Fontes, M.P.F.; Schaefer, C.E.G.R. 2000. Potassium and magnesium minerals from sand and silt fractions of different soils. Revista Brasileira de Ciência do Solo 24: 269284. (in Portuguese, with abstract in English)

Oliveira, T.S. 1996. Heavy metals as indicators of materials of soil. Dr. Thesis. Universidade Federal de Viçosa, Viçosa, MG. Brazil. 128p. (in Portuguese, with Summary in English).

Qian, J.; Wang, Z.; Shan, X.; Tu, Q.; Wen, B.; Chen, B. 1996. Evaluation of plant availability of soil trace metals by chemical fractionation and multiple regression analysis. Environmental Pollution 91: 309-315.

Ramalho, J.F.P.G.; Amaral Sobrinho, N.M.B.; Velloso, A.C.X. 2000. Contamination of the watershed of Caetes with heavy metals by the use of agrochemicals. Pesquisa Agropecuária Brasileira 35: 1289-1303. (in Portuguese, with abstract in English).

Ribeiro, L.P. 1996. Genesis, evolution and degradation of yellow cohesive coastal plain. p. 27-37. In: Nogueira, L.R.Q.; Nogueira, L.C., eds. Pesquisa e desenvolvimento para os tabuleiros costeiros. Embrapa Tabuleiros Costeiros, Aracajú, SE. Brazil.

Ross, S.M. 1994. Toxic Metals in Soil Plant Systems. John Willey, Chichester. UK. 469p.

Rovers, H.; Camargo, O.A.; Valadares, J.M.A.S. 1983. Nickel total soluble and DTPA in soils of the State of Sao Paulo. Revista Brasileira de Ciências do Solo 7: 217-220. (in Portuguese, with abstract in English)

Saldanha, M.F.C.; Pérez, D.V.; Meneguelli, N.A.; Moreira, J.C.; Vaitsman, D.S. 1997. Evaluation of five types of opening to determine the levels of iron, manganese and zinc in some Brazilian soils. Pesquisa em Andamento 1: 1-10. (In Portuguese)

Santos Filho, A.; Rocha, H.O. 1982. Copper in soils of the State of Paraná. Revista do Setor de Ciencias Agrárias 4: 23-26. (in Portuguese, with abstract in English)

Souza, M.L.P.; Andreoli, C.V.; Amaral, M.B.; Domaszak, S.C. 1996. Preliminary survey of heavy metal content in some soils of Paraná. Sanare. Revista Técnica da Sanepar 5: 68-75. (in Portuguese)

StatSoft. 1995. StatSoft Statistics for Windows: Computer Program Manual. StatSoft, Tulsa, OK. USA.

Tiller, K.G. 1989. Heavy metals in soil and their environmental significance. Advances in Soil Science 9: 113-142.

UNITED STATES DEPARTMENT OF AGRICULTURE [USDA]. 1999. Natural Resources Conservation Service. Soil Survey Staff. Soil Taxonomy, a Basic System of Soil Classification for Making and Interpreting Soil Surveys. 2ed. USDA, Washington, D.C., USA. 169p. (Agriculture Handbook, 436).,

Valadares, J.M.A.S. 1975. Copper in soils of the State of Sao Paulo: total copper. Bragantia, 34: 125-132. (in Portuguese, with abstract in English)

Valadares, J.M.A.S.; Catani, R.A. 1975. Zinc in soils of the State of São Paulo: total zinc. Bragantia 34: 134-139. (in Portuguese, with abstract in English)

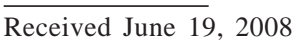

Accepted September 29, 2009 